\title{
Zinc in Urban/Peri-Urban Agriculture in Bamako, Mali: Effects of Closing the Nutrient Loop
}

\author{
SanataTraore $^{1}$, Alou Barry ${ }^{2}$, Brahima B. Traore ${ }^{2 *}$, Souleymane Dambe ${ }^{1}$, Boubacar Traore ${ }^{2}$, \\ Adama Diallo ${ }^{1}$, Mama Plea ${ }^{1}$, Cheick Dembele ${ }^{1}$, Gunnar Jacks ${ }^{3}$ \\ ${ }^{I}$ Faculty of Sciences and Technics, University of Sciences, Technics and Technologies of Bamako - Mali \\ ${ }^{2}$ Institute of Applied Sciences, University of Sciences, Technics and Technologies of Bamako - Mali \\ ${ }^{3}$ Division of Water and Environmental Engineering, Royal Institute of Technology(KTH), Stockholm, Sweden. \\ *Corresponding Author:Brahima B Traore, Department of Applied Chemistry of Institute of Applied \\ Sciences (ISA) -University of Sciences, Technics and Technologies of Bamako - Mali,
}

\begin{abstract}
Gardening for the local market is fast increasing in suburban Bamako. Its development is explained by the increased demand for fruits and vegetables. The activity is mainly practised by women. The gardening significantly contributes to maintaining a balanced diet. Besides being an important plant nutrient, zinc is essential for human health. Zinc deficiency is common in semi-arid West Africa.
\end{abstract}

Thus, the aim of this work has been to determine the available zinc content in the garden land, which is essential for plant growth as well as to ensure a healthy, balanced diet for the population.

The samples were taken from large production sites. The following analyses were made: pH, texture, organic matter, total metals and the sequential extraction of trace metals ( $\mathrm{Zn}, \mathrm{Fe}, \mathrm{Cu}, \mathrm{Mn})$. In addition, exchangeable cations and DTPA-extractable $\mathrm{Zn}, \mathrm{Cu}, \mathrm{Fe}$ and $\mathrm{Mn}$ were carried out to characterise the physical and chemical properties of these soils.

The results showed that the soils have a pH between 5.74 and 7.61 with a mean $p H=6.5$, which is recognised as the optimum $\mathrm{pH}$ for nutrient availability. Zn extractable contents are between $7.28 \mathrm{ppm}$ and $0.39 \mathrm{ppm}$. New practices in the form of urine-separating latrines and the co-composting of urine with organic wastes to gain a soil amendment have contributed to closing the loop of nutrients among them zinc. The content of organic matter in the soil amendments is another favourable factor from the recycling practised in Bamako.

Vegetables grown in the urban/peri-urban gardens have zinc concentrations in the same range as reference values from the literature indicating that the soil environment is good, producing vegetables of good quality. Potentially toxic metals like lead and cadmium are low.

Zinc bioconcentration factors greater than 1 indicate that these vegetables can play an interesting role in nutritional intake

Keywords:Soil, Gardening, Urban, Peri-urban, Zinc

\section{INTRODUCTION}

Zinc is an essential element for plants and humans.However, zinc deficiency in soils is common globally(Cakmak 2009) and not least in Africa(Buri et al. 2000; Gårdestedt et al, 2009).Adequate zinc is a cornerstone of global maternal and child health, and roughly $17 \%$ of the global population are estimated to be at risk of having a zinc deficiency (Myers et al. 2014). There is a tendency that essential trace elements like copper and zinc, are decreasing in food items. This is due to dilution as crop yields increase with the use of commercial fertilisers (Marles 2017). This is also known as the "green revolution". As the fertiliser addition is often just nitrogen, phosphorus and potassium, there is also a slow "mining" of trace elements from soils by the uptake to crops. Another dilution effect will be seen if the carbon dioxide in the atmosphere increases from the current $380 \mathrm{ppm}$ to $550 \mathrm{~mm}$ in the future (Myers et al. 2014; Myers et al 2015). Zinc has numerous functions in organisms since it is part of hundreds of enzymes.Selected problems of zinc deficiency in food chains from soils to humans are: lower crop yields, especially of wheat(Kalayci et al. 1999),skin affections in animals, decreased 
immune competence in humans, especially resulting in diarrhoea in children (Walker and Black 2004; Liberato et al. 2015). Zinc deficiency is recognised by many experts as a major public health problem.In sub-Saharan Africa zinc deficiency might be more widespread than iron deficiency (Motadi et al. 2015; Gregory et al. 2017). In the Niger inland delta zinc deficiency in soil has been found almost everywhere (Gårdestedt et al. 2009).Zinc deficiency in the Niger inland valley has made it difficult to introduce the common crop rotation with rice during the wet season and wheat during the dry as wheat is particularly prone to be affected by zinc deficiency(Cakmak 2008). It has been considered that zinc and iron compete for the same uptake mechanisms in humans. However later research considers that there is rather a synergy in the uptake of vitamin A, iron and zinc (Graham et al. 2012). Approximately $25 \%$ of the West African population consume food that is zinc deficient (Wessels and Brown 2012). Zinc is important for immune defence and zinc deficiency is known as one of the major reasons for mortality due to malaria,diarrhoea and respiratory diseases(Fischer Walker and Black 2004; Fischer Walker et al. 2009).In some publications the prevalence of zinc deficiency is higher than iron deficiency in girls than in boys (Motadi et al. 2015). Child mortality is high in Mali, 220/1000 before the age of 5 years. The mortality is especially accumulated at two periods: at birth,due to a lack of midwifes and inthe weaning period from 6 to 9 months of age (Jacks et al. 2011).In Mali this has initiated the introduction of zinc to children with diarrhoea along with the use of ORS (oral rehydration solution) (Ellis et al. 2007). Similar results are obtained in Burkina Faso (Wessels et al. 2012). Santhosham et al. (2010) give a review of the problems with diarrhoea. Individuals infected with HIV are particularly prone to zinc deficiency (Zhang et al. 2015). In patients infected with HIV, a link was observedbetween zinc levels in the blood and an increased risk of disease progression, as well a higher risk of mortality. Plant availability of zinc in soilis influenced by many factors such as: high clay, high $\mathrm{pH}$, excess phosphate, highAl- and Fe-oxides and low inherent zinc levels (Gårdestedt et al. 2009) (Fig. 1). DTPA extraction is a long-term and well-accepted way to assess zinc availability in soils for plants(Lindsay and Norvell 1978). However, carboxylic organic acids might bean alternative (Lombnaes et al. 2008). Zinc has many functions in plants. It's important in the early stages of growth and seed formation.Zinc also plays a role in the production of chlorophyll and carbohydrates. Zinc deficiency is often seen as chlorosis.

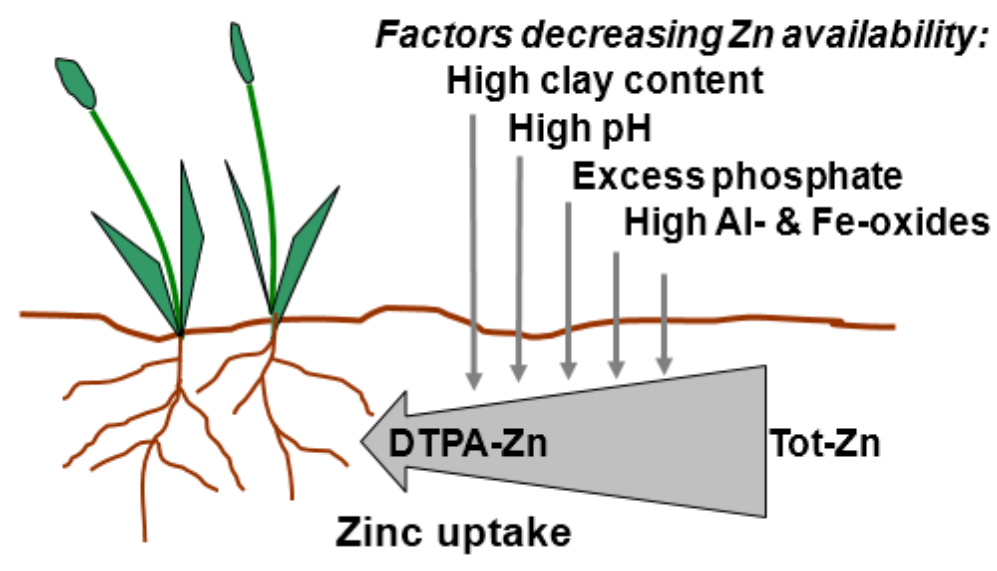

Fig1.Factors affecting the plant availability for plants. In addition to the factors given here it can be noted that zinc availability is positive correlated to organic carbon in soil (Rahman et al. 2007).

Urbanisation is fast progressing in Sub-Saharan Africa. In $200832 \%$ of the population of Mali lived in urban areas (World Factbook 2010). By $202460 \%$ are expected to stay in urban agglomerations. In parallel to that, urban and peri-urban agriculture gains importance (Drechsel and Dongus 2010; Dossa et al. 2010). Sidibé (2000) has stated that there are 1780 registered farmers within the boundaries of the capital Bamakoand that made the city more or less self-sufficient in vegetables. However, urban and peri-urban agriculture is vulnerable as most cultivators do not own the land and urbanisation tends to demand more land (Samba 2010). In Mali 137-275 g/day of vegetables are consumed per capita (Orsini et al. 22013). Urban and peri-urban gardens contribute significantly to the maintenance of a balanced diet. $\square$-carotene in carrots and leafy, green vegetables are important for the bio-accessibility of zinc and iron from food grains (Gautam et al. 2010). 


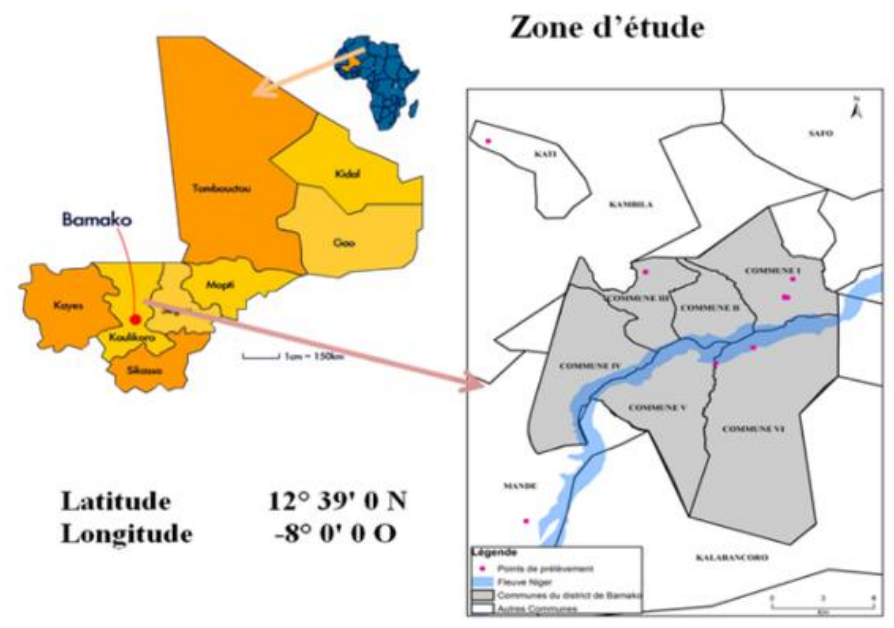

Fig2.Sampling points in Bamako, Mali.

In seeds, zinc and trace metals are especially concentrated in the outer portions of the grain and are tied to phytic acid. When the grain starts to sprout there is an enzyme that degrades the phytate and makes the trace metals available for the growing plant (Khoskhar and Khoskhar 1996). Thus, the sprouting of seeds makes zinc more available. The ratio of $\mathrm{Zn} /$ phytatein food is an important parameter to assess the zinc availability in food.

A development that has favoured urban and peri-urban agriculture is the increasing use of urine separating latrines in Bamako and Mali (Shaw 2010; PetterssonandWikström 2016). This is a development that has been forwarded by the Burkina Faso based organisation WSA (Water and Sanitation for Africa) throughlocal agents in Bamako. The urine-separating latrines protect the groundwater and the urine can be used as a fertiliser (Shaw 2010). One problem in this area has been the storage of urine during the dry period when less agriculture is practised. in Bamako this has been solved by co-composting the urine with organic waste. The high temperature in composting hygienizes the urine and waste (Morgan 2007)and produces a good soil amendment that has been studied in this report.

\section{Materials ANd Methods}

The soil samples are taken at large production sites around Bamako (fig. 1). The samples are taken at 0-20 cm depth.Sampling points were geo-referenced.The samples are numbered as follows: B1: Dianéguela; B2: Samanko; B3:Magnambougou; B4: Baguineda;B5:KorofinaSud; B6:Kogniba.There are six (6) samples in total.

Samples were sieved through a $2 \mathrm{~mm}$ sieve. Texture was determined with the Robinson pipette method as sand $(2-0.2 \mathrm{~mm})$, into silt $(0.2-0.002 \mathrm{~mm})$ and clay $(<0.002 \mathrm{~mm})$. The $\mathrm{pH}$ of the soil was measured with a $\mathrm{pH}$ meter (HANNA, HI2210) at a soil/water ratio 1:2.5. The organic carboncontent was determined using the method designed by Anne (Anne 1945; McCarty et al. 2010) and the available phosphorus usingthe Bray no 2 method (Bray and Kurz 1945). Exchangeable cations were determined by atomic absorption spectroscopy after extraction with $0.5 \quad \mathrm{~N} \quad \mathrm{BaCl}_{2}$ in 0.2 Mtriethanolamine adjusted to $\mathrm{pH} 8.2$ with $\mathrm{HCl}$. Available $\mathrm{Zn}, \mathrm{Fe}, \mathrm{Cu}$ and $\mathrm{Mn}$ were obtained using DTPA extraction following the method of Lindsay (1972). The concentrations of these elements were determined done with AAS (Varian AA55). Total elemental analysis was made by ACME Analytical Laboratories in Vancouver, Canada with ICP-MS after aqua regia digestion. Sequential extraction was done using the BCR method (Zemberyová et al. 2006). This method results in three extracts by 0.11 $\mathrm{M}$ acetic acid, 0.5 $\mathrm{M}$ hydroxylamine hydrochloride and $8.8 \mathrm{M} \mathrm{H}_{2} \mathrm{O}_{2}$.

Table1.Name and samples references

\begin{tabular}{|l|l|l|l|l|l|l|}
\hline Sample & Location & $\begin{array}{l}\text { Longitude } \\
\text { Latitude }\end{array}$ & Texture & Fertiliser & $\begin{array}{l}\text { Watter } \\
\text { supply }\end{array}$ & Land use \\
\hline B1 & Dianeguela & $\begin{array}{l}0613352 \\
1399117\end{array}$ & Silty sand & $\begin{array}{l}\text { Organic } \\
\text { manure,DAP* }\end{array}$ & Shallow well & Lettuce \\
\hline B2 & Samanko & $\begin{array}{l}0600243 \\
1384366\end{array}$ & Sandy & $\begin{array}{l}\text { Organic } \\
\text { manure,DAP* }\end{array}$ & $\begin{array}{l}\text { Shallow } \\
\text { well }\end{array}$ & Carrote \\
\hline
\end{tabular}




\begin{tabular}{|l|l|l|l|l|l|l|}
\hline B3 & Magnambougou & $\begin{array}{l}0611204 \\
1394727\end{array}$ & Sandy & $\begin{array}{l}\text { Cow manure, } \\
\text { NPK }\end{array}$ & Shallow well & Lettuce \\
\hline B4 & Baguinéda & $\begin{array}{l}0632622 \\
1395646\end{array}$ & Sandy silt & $\begin{array}{l}\text { Organic } \\
\text { manure,NPK }\end{array}$ & Stream & Tomato/onion \\
\hline B5 & Korofina-Sud & $\begin{array}{l}0615155 \\
1399117\end{array}$ & Silty sand & $\begin{array}{l}\text { Organic } \\
\text { manure }\end{array}$ & Shallow well & Celery \\
\hline B6 & Kogniba & 0633831 & Silty sand & Droppings & Shallow well & Rice/onion \\
\hline
\end{tabular}

*DAP = diammonium-phosphate

\section{RESULTS AND DISCUSSION}

The results are given in the following tables. Table 2shows that the soilsare mostly sandy except for B1 which is silty. There are acidic soils with a $\mathrm{pH}$ between $5.5-6$, anda good availability of trace element for plants,and soils approaching neutrality with a $\mathrm{pH}$ between 6.5-7.0at which trace elements which are readilyavailable for plants. The slightly acidic $\mathrm{pH}$ is explained by the content of organic matter and the composition of exchangeable cations.

Tables 3and 4 show values for DTPA and sequential extractions. DTPA extraction showsthe highest value in B1 with $7.28 \mathrm{mg} / \mathrm{kg}$ and the lowest at $0.398 \mathrm{mg} / \mathrm{kgin} \mathrm{B} 4$. B1 with a $\mathrm{pH}=6.5$ at which all nutrients elements are available to plants, has high values for zinc, organic matter, and phosphorus. The available zinc content is fairin other samples as zinc deficiency assessed by DTPA extraction is considered to exist below a range of $0.5-2.0 \mathrm{mg} / \mathrm{kg}$ (Sims and Johnson 1991). Rahman et al. (2007) gives the critical level of DTPA extractable zinc at $0.8 \mathrm{mg} / \mathrm{kg}$ for rice in calcareous soils. The phosphorus concentration is not high enough to inhibit zinc availability.

Table2.pH, texture, organic matter andexchangeable cations in garden soils.

\begin{tabular}{|l|l|l|l|l|l|l|l|l|l|}
\hline Sample & $\mathrm{pH}$ & $\begin{array}{l}\text { Sand } \\
\%\end{array}$ & $\begin{array}{l}\text { Silt } \\
\%\end{array}$ & $\begin{array}{l}\text { Clay } \\
\%\end{array}$ & $\begin{array}{l}\mathrm{OM} \\
\%\end{array}$ & $\begin{array}{l}\mathrm{Ca}^{2+} \\
\mathrm{meq} / 100 \mathrm{~g}\end{array}$ & $\begin{array}{l}\mathrm{Mg}^{2+} \\
\mathrm{meq} / 100 \mathrm{~g}\end{array}$ & $\begin{array}{l}\mathrm{K}^{+} \\
\mathrm{meq} / 100 \mathrm{~g}\end{array}$ & $\begin{array}{l}\mathrm{Na}^{+} \\
\mathrm{meq} / 100 \mathrm{~g}\end{array}$ \\
\hline B1 & 6.50 & 31 & 68 & 1 & 7.6 & 9.70 & 4.84 & 0.50 & 0.56 \\
\hline B2 & 6.72 & 84 & 13 & 3 & 1.4 & 1.09 & 0.54 & 0.09 & 0.06 \\
\hline B3 & 6.67 & 86 & 12 & 6 & 4.4 & 5.05 & 2.72 & 0.16 & 0.28 \\
\hline B4 & 5.85 & 55 & 43 & 2 & 2.2 & 2.48 & 1.15 & 0.13 & 0.06 \\
\hline B5 & 5.67 & 83 & 13 & 4 & 2.1 & 2.48 & 1.13 & 0.17 & 0.22 \\
\hline B6 & 5.69 & 77 & 28 & 2 & 1.3 & 1.58 & 0.73 & 0.09 & 0.06 \\
\hline
\end{tabular}

Table3.Total and DTPA extractable metals in garden soils.

\begin{tabular}{|l|l|l|l|l|l|l|l|l|l|}
\hline Sample & $\begin{array}{l}\text { Zn } \\
\text { total }\end{array}$ & $\begin{array}{l}\text { Zn } \\
\text { DTPA } \\
\text { ppm }\end{array}$ & $\begin{array}{l}\text { Cu } \\
\text { total } \\
\text { ppm }\end{array}$ & $\begin{array}{l}\text { Cu } \\
\text { DTPA } \\
\text { ppm }\end{array}$ & $\begin{array}{l}\text { Fe total } \\
\%\end{array}$ & $\begin{array}{l}\text { Fe } \\
\text { DTPA } \\
\text { ppm }\end{array}$ & $\begin{array}{l}\text { Mn } \\
\text { total } \\
\text { ppm }\end{array}$ & $\begin{array}{l}\text { Mn } \\
\text { DTPA } \\
\text { ppm }\end{array}$ & $\begin{array}{l}\text { P } \\
\text { avail. } \\
\text { ppm }\end{array}$ \\
\hline B1 & 103 & 7.28 & 14 & 1.08 & 1.46 & 15.9 & 257 & 9.01 & 160 \\
\hline B2 & 17 & 3.22 & 2 & 0.156 & 0.96 & 1.90 & 104 & 0.47 & 47.2 \\
\hline B3 & 68 & 2.24 & 8 & 0.884 & 1.57 & 15.8 & 246 & 6.65 & 139 \\
\hline B4 & 10 & 0.398 & 3 & 0.450 & 0.57 & 88.4 & 57 & 6.52 & 120 \\
\hline B5 & 12 & 3.00 & 4 & 0.310 & 0.62 & 17.3 & 193 & 34.6 & 129 \\
\hline B6 & 15 & 3.84 & 2 & 0.216 & 0.37 & 40.5 & 90 & 7.66 & 88.9 \\
\hline
\end{tabular}

Table4.Sequential extraction of zinc with the BCR method (Zemberyová et al. 2006).

\begin{tabular}{|l|l|l|l|l|l|l|}
\hline Fraction & $\mathrm{B} 1 \mathrm{mg} / \mathrm{kg}$ & $\mathrm{B} 2 \mathrm{mg} / \mathrm{kg}$ & $\mathrm{B} 3 \mathrm{mg} / \mathrm{kg}$ & $\mathrm{B} 4 \mathrm{mg} / \mathrm{kg}$ & $\mathrm{B} 5 \mathrm{mg} / \mathrm{kg}$ & $\mathrm{B} 6 \mathrm{mg} / \mathrm{kg}$ \\
\hline Acetate leachable & 0.4 & 8 & 19 & 4.9 & 5.1 & 7.0 \\
\hline Reducible & 40 & 4,0 & 27 & 4.1 & 4.2 & 3.1 \\
\hline Organic matter & 16 & 5.8 & 11 & 3.0 & 3.0 & 4.4 \\
\hline Residual & 47 & 0.2 & 11 & $<1$ & $<1$ & $<1$ \\
\hline Total & 103 & 17 & 68 & 12 & 12 & 15 \\
\hline
\end{tabular}

Generally the soils are less deficient than those studied along a $700 \mathrm{~km}$ stretch in the River Niger Inland Delta (Barry et al. 2009; Gårdestedt et al. 2009). Only B4 has very low DTPA available zinc.

A few samples of soil amendments produced by composting have been collected and analysed. The content of organic matter is favourably high as is the zinc content while potential toxic lead and cadmium are low. Thus, the recycling of organic waste seems to be very favourable and without negative effects regarding trace metals. 
Table5.Soil amendments used in suburban agriculture. Global average contents of heavy metals in soils after Alloway (2012).

\begin{tabular}{|l|c|c|c|c|c|c|c|c|c|c|c|}
\hline Site & $\mathrm{pH}$ & $\begin{array}{c}\text { Tot- } \\
\mathrm{C} \%\end{array}$ & $\begin{array}{c}\text { Tot- } \\
\mathrm{N} \%\end{array}$ & $\begin{array}{c}\mathrm{Cu} \\
\mathrm{mg} / \mathrm{kg}\end{array}$ & $\begin{array}{c}\mathrm{Pb} \\
\mathrm{mg} / \mathrm{kg}\end{array}$ & $\begin{array}{c}\mathrm{Zn} \\
\mathrm{mg} / \mathrm{kg}\end{array}$ & $\begin{array}{c}\mathrm{Cd} \\
\mathrm{mg} / \mathrm{kg}\end{array}$ & $\mathrm{P} \%$ & $\begin{array}{c}\mathrm{DTPA} \\
\mathrm{Zn} \\
\mathrm{mg} / \mathrm{kg}\end{array}$ & $\begin{array}{c}\text { DTPA } \\
\mathrm{Cu} \\
\mathrm{mg} / \mathrm{kg}\end{array}$ & $\begin{array}{c}\text { DTPA } \\
\mathrm{Cd} \\
\mathrm{mg} / \mathrm{kg}\end{array}$ \\
\hline Baguinéda & 8.8 & 11.5 & 0.67 & 19.4 & 13.5 & 88 & 0.2 & 0.233 & 13.9 & 1.12 & 0.05 \\
\hline Dianéguela & 7.8 & 16.1 & 1.63 & 36.4 & 16.9 & 183 & 0.2 & 0.476 & 39.2 & 4.00 & 0.09 \\
\hline Koulouba & 8.4 & 7.90 & 0.79 & 26.4 & 14.7 & 146 & 0.3 & 0.312 & 18.3 & 1.82 & 0.07 \\
\hline Magnambougou & 7.1 & 13.8 & 1.45 & 34.9 & 24.3 & 324 & 0.3 & 0.802 & 44 & 4.40 & 0.08 \\
\hline $\begin{array}{l}\text { Global soil } \\
\text { average }\end{array}$ & & & & 42 & 25 & 62 & 1.1 & & & & \\
\hline
\end{tabular}

Some garden crops have been collected and investigated. They show values in the same range as reference values available from Egypt (Radwan and Salama 2006) and collected from Wikipedia. This indicates that the recycling of zinc may have had a certain influence. A number of the organic amendments analysed show a quite high content of zinc, while the cadmium content is low and there is no excess of the other metals analysed. The availability of zinc as analysed by DTPA-extraction is high and likely to depend on the elevated organic carbon content.

Table6.Zinc in vegetables cultivated in suburban gardens in Bamako and references values from the literature. Metal contents in $\mathrm{mg} / \mathrm{kg}$ dry weight.

\begin{tabular}{|l|l|l|l|l|l|l|l|l|}
\hline Site & Vegetable & $\begin{array}{l}\mathrm{Cu} \\
\mathrm{mg} / \mathrm{kg}\end{array}$ & $\begin{array}{l}\mathrm{Zn} \\
\mathrm{mg} / \mathrm{kg}\end{array}$ & $\begin{array}{l}\mathrm{Cd} \\
\mathrm{mg} / \mathrm{kg}\end{array}$ & $\begin{array}{l}\mathrm{Fe} \\
\mathrm{mg} / \mathrm{kg}\end{array}$ & $\begin{array}{l}\mathrm{Mn} \\
\mathrm{mg} / \mathrm{kg}\end{array}$ & $\begin{array}{l}\text { Zn ref. } \\
\mathrm{mg} / \mathrm{kg}^{1}\end{array}$ & $\begin{array}{l}\text { Zn ref. } \\
\mathrm{mg} / \mathrm{kg}^{2}\end{array}$ \\
\hline Samanko & Carrot & 3.3 & 11.9 & 0.80 & 73.8 & 24.2 & 8.03 & 16.6 \\
\hline Soterco & Celery & 3.9 & 39.4 & 0.90 & 583 & 57.8 & - & 28.4 \\
\hline Dianéguela & Lettuce & 5.5 & 27.8 & 1.0 & 1359 & 36.5 & 9.76 & 45.7 \\
\hline Magnambougou & Lettuse & 5.5 & 41.1 & 0.95 & 1024 & 30.9 & 9.76 & 45.7 \\
\hline Baguinéda & Onion & 3.9 & 19.7 & 0.45 & 28.5 & 9.6 & 11.4 & 15.6 \\
\hline Baguinéda & Onion & 2.9 & 31.5 & 0.50 & 53.9 & 19.0 & 11.4 & 15.6 \\
\hline Kolouba & Tomato & 6.2 & 22.3 & 0.75 & 410 & 10.3 & 7.69 & - \\
\hline Kati & Beetroot & 10.9 & 22.6 & 0.55 & 71.2 & 10.7 & - & 24 \\
\hline
\end{tabular}

${ }^{1}$ Reference values from Egypt (Radwan and Salama 2006) ${ }^{2}$ Reference values from Wikipedia

\section{CONCLUSION}

Zinc is an element that is usually found in trace amounts in soils. Malian soils are deficient in zinc (Gårdestedt et al. 2009),but in this study, soils used for growing vegetables in suburban areas are relatively rich in zinc.As per Alloway (2008) zinc content in sandy soils ranges from about 10 to 300 $\mathrm{mg} / \mathrm{kg}$ with a mean content of $50 \mathrm{mg} / \mathrm{kg}$ and a median content of about $40 \mathrm{mg} / \mathrm{kg}$. Thus, among the studied soils, B1 and B3 have good amounts of zinc, while the others have a low content. The relatively good zinc status of these soils is probably due to the use of manure and organic matter derived from the habitation where considerable amounts of zinc are recycled from galvanized roofs (Chang et al. 2004) and from dry batteries etc. In many cases, it is possible to see a gradually decreasing trace metal content from urban to suburban areas (Maas et al. 2010) as well as around villages in the Malian country side (Gårdestedt et al. 2009). What is encouraging is that trace metal pollution seen in many urban and suburban areas globally is not a threat in Bamako (Luo et al. 2012).

In general, African solid waste has less heavy metals than what is found in industrialized countries (Adjia et al. 2008). The use of organic waste as fertiliser has already been organised rather long time in Mali (Eaton and Hilhorst 2003; Pettersson and Wikström 2016). Solid waste in developing countries has less metal content than that found in industrialised countries and zinc seems to be the most abundant metal (www.globenet.org/preceup/pages/fr/chapitre/reflreco/reflex/asptecja_c.thm). In Mali the use of dry batteries for radios etc, amounts to about $400 \mathrm{~g}$ zinc/person/year. The use of compost in two Malian soils was found to increase the uptake of zinc and other trace metals when compared to mineral fertiliser only (Soumaré et al. 2003). Phosphorus is commonly deficient in Malian soils. Unfortunately, most phosphates contain several tenths of $\mathrm{mg} / \mathrm{kg}$ cadmium (Roberts 2014) which is taken up by plants in a similar way as zinc. To the extent indigenous phosphates can be used in Mali it is noticeable that the Tilemsiphosphate deposit has a cadmium concentration below $1 \mathrm{ppm}($ GreatQuestfertilizer 2011).The sources of zinc found in the Bamako habitat, galvanized roofs and batteries and are not accompanied to any appreciable extent by cadmium. 
Zinc deficiency in soil is common in Mali (Gårdestedt et al. 2009). This investigation shows that the total zinc content is low except for in samples B1 and B3. The zinc presence is, however,quite plant available due to the slightlyacidic $\mathrm{pH}$. Only one sample, $\mathrm{B} 4$ falls under what is considered as a serious zinc deficiency. The recycling of organic waste composted with urine from urine-separating latrines, which is common in Bamako, yields a soil amendment that has a favourable composition, is high in organic matter and has quite a high zinc content, while other metals, especially the non-essential and potentially toxic lead and cadmium are low. Part of the elevated zinc content probably originates from galvanised roofs and used batteries (Gårdestedt et al. 2009). The vegetables produced in the suburban gardens have zinc contents at the same level as reference data from Egypt (Radwan and Salama 2006) and data collected from Wikipedia. Garden products are important for nutrition in urban Bamako. Even if vegetables have moderate amounts of zinc there is an important secondary effect of $\square$ carotene in leafy green vegetables that help in making zinc from food grains more available (Gautam et al. 2010).

\section{ACKNOWLEDGEMENT}

This research was carried out at the Swedish Royal Institute of Technology, with funding from the University of Uppsala through their International Science Programme project. We sincerely thankthe director of this programme.In addition,we thank our colleagues who helped directly or indirectly in carrying out the study.

\section{REFERENCES}

[1] Adjia, R., Fezeu, W. M., Tchatchueng, J. B. et al. (2008). Long term effect of municipal solid waste amendment on soil heavy metal content on sites used for peri-urban agriculture in Ngaoundere, Cameroon.African Journal of Environmental Scienceand Technology, 2(12), 412-421.

[2] Alloway, B. J. (2008).Zinc in soils and crops nutrition. Int. Zinc Assoc. and Fertilizer Assoc. $2^{\text {nd }}$ edition. Brussels and Paris. 135 pp.

[3] Alloway, B. J. (2012).Heavy metals in soils. $3^{\text {rd }}$ Edition. Springer Verlag. 614 pp.

[4] Anne, P. (1945). Carbone organic (total) du sol et du humus. Annals of Agronomy, 15, 161-172.

[5] Barry, A., Jacks, B. \& Jacks, G. (2009). Zinc deficiency in soils, crops and food in Mali and options for remediation. Epidemiology, 20(6), 14.

[6] Bray, R. H. \&Kurz, L.T. (1945). Determination of total organic and available forms of phosphorus in soil. Soil Science, 59, 39-45.

[7] Buri, M.M., Masunga, T. \&Wakatsuki, T. (2000).Sulfur and zinc levels as limiting factors to rice production in West Africa. Geoderma 94, 23-42.

[8] Cakmak, I. (2008). Zinc deficiency in wheat in Turkey. Chapter 7 (pp 181-200) in Micronutrient Deficiencies in Global Crop Production, Ed. B.J. Alloway. Springer Science+Business Media. pp

[9] Cakmak, I. (2009). Enrichment of fertilizers with zinc: An excellent investment for humanity and crop production in India. Journal of Trace Elements in Medicine and Bioliology, 23, 281-289.

[10] Chang, M., McBroom, M.W. \& Beasley, R. S. (2004). Roofing as a source of nonpoint water pollution. Journal of Environmental Management, 73, 307-315.

[11] Dossa. L. H., Abementdulkadir, A., Amadou, H. et al.(2011). Exploring the diversity of urban and periurban agricultural systems in Sudano-Sahelian West Africa: An attempt towards a regional typology. Landscape and Urban Planning 102, 197-206.

[12] Drechsel, P. \&Dongus, S. (2010). Dynamics and sustainability of urban agriculture: examples from sub.Saharan Africa. Sustainable Science. 5, 69-78.

[13] Eaton, C. \&Hilhorst, T. (2003). Opportunities for managing solid waste flows in the peri-urban interface of Bamako and Ougadougou. Environment and Urbanisation, 5(1), 53-63.

[14] Ellis, A. A., Winch, P., Daou, Z. et al. (2007). Home management of childhood diarrhoea in southern Mali - Implications for the introduction of zinc treatment. Social Science and Medicine, 64, 701-714.

[15] Fischer Walker, C. \& Black, R. E. (2004). Zinc and risk for infectious disease. Annual Reviewin Nutrition, 24, 255-275.

[16] Fischer-Walker, C. L., Ezzati, M. \& Black. R. E. (2009). Global and regional child mortality and burden of disease attributable to zinc deficiency. European Journal inClinical Nutrition, 63, 591-597.

[17] Gårdestedt, C., Plea, M., Nilsson, G. et al.(2009). Zinc in soils, crops and meals in the Niger Inland Delta, Mali. Ambio, 38(8), 334-338. 
[18] Gautam, S., Platel, K. \& Srinivasan, K. (2010). Influence of $\square$-carotene-rich vegetables on the bioaccessibility of zinc and iron from food grains. Food Chemistry, 122, 668-672.

[19] Graham, R. D., Knez, M. \& Welch, R. M. (2012). How much nutritional iron deficiency in humans globally is due to an underlying zinc deficiency? In Advances in Agronomy Vol. 115, Chapter 1: 1-40.

[20] GreatQuestfertilizer (2011).Tilemsi phosphate deposit. www.greatquest.com/pages/projects/phosphate.

[21] Gregory, P. J., Wabhi, A., Adu. Gyamfi, J., Heiling, M., Gruber, R., Joy, E. J. M., Broadley, M. R. (2017). Approaches to reduce zinc and iron deficits in food systems. Global Food Security, xx: xxxxxx.http://dx.doi.org/10.1016/j.gfs.2017.03.003.

[22] Jacks, B., Sall, M.\& Jacks, G. (2011).Breastfeeding and weaning in a village in the Niger Inland Delta, Mali. African Journal of Midwifery 5(1), 9-14.

[23] Kalayci, M., Torun, B.,Eher, S. et al. (1999). Grain yield, zinc deficiency and zinc concentrations of wheat cultivars grown in a zinc deficient calcareous soil and greenhouse. Field Crops Research, 63,87-98.

[24] Khoskhar, P. \&Khoskhar, S. (1996). In vitro availability of iron and zinc from some Indian vegetarian diets: correlation with dietary fibre and phytate. Food Chemistry, 56(2), 111-114.

[25] Liberato, S. C., Singh, G., Mulholland, K. (2015). Zinc supplementation in young children: A review of literature focusing on diarrhoea prevention and treatment. Clinical Nutrition, 34: 181-188.

[26] Lindsay, W. L.\&Norvell, W. A. (1978).Development of a DTPA soil test for zinc, iron, manganese and copper.Soil Science Society of America Journal, 42,421-428.

[27] Lombnaes, P., Changh, A.C. \& Singh, B. R. (2008). Organic ligand, competing cation and pH effects on dissolution of zinc in soil. Pedosphere 18(1), 92-101.

[28] Luo, X., Yu, S., Zhu, Y. et al.(2012). Trace metal contamination in urban soils of China. Science of the Total Environment, 421-422,17-30.

[29] Maas, S., Scheifler, R., Benslama, M. et al. (2010). Spatial distribution of heavy metal concentrations in urban, suburban and agricultural soils in a Mediterranean city of Algeria. Environmental Pollution, 158, 2294-3201.

[30] Marles, R. J. (2017). Mineral nutrient composition of vegetables, fruits and grains: The context of reports of apparent historical declines. Journal of Food Composition and Analysis, 56, 93-103.

[31] McCarty, G. W., Reeves III, J., B., Yost, R. et al. (2010). Evaluation of methods for measuring soil organic carbon in West African soils. African Journal of Agricultural Research 5(16), 2169-2177.

[32] Morgan, P. (2007).Latrines à compost.Stockholm Environment Institute.EcoSanRes Programme. 110 pp.

[33] Motadi, S. E., Mbhenyane, X. G., Mbhatsani, H. V. et al.(2015). Prevalence of iron and zinc deficiencies among preschool children ages 3 to 5 years in Vhembe district,Limpopo province, South Africa. Nutrition $31,452-458$.

[34] Myers, S. S., Zanobetti, A., Kloog, I. et al. (2014). Increasing $\mathrm{CO}_{2}$ threatens human nutrition. Nature 510,139-142.

[35] Myers, S. S., Wesells, K. R., Kloog, I. et al. (2015). Effect of increased concentrations of atmospheric carbon dioxide and the global threat of zinc deficiency: a modelling study. The Lancet 3(10), 639-645.

[36] Orsini, F., Kahane, R., Nono-Womdim, R, Gianquinto et al. (2013). Urban agriculture in the developing world; a review. Agronomy and Sustainable Development, 33, 695-720.

[37] Pettersson, J. and Wikström, J. (2016).Human fertilizer and the productivity of farming households. Agroecology and Sustainable Food Systems, 40(1),48-68.

[38] Radwan, M. A. \&Salama, A. K. (2006). Market basket survey for some heavy metals in Egyptian fruits and vegetables. Food Chemistry and Toxicology, 44, 1273-1278.

[39] Rahman, M. A., Jahiruddin, M. \& Islam, M. R. (2007) Critical limit of zinc for rice in calcerous soils. Journal of Agricultural and Rural Development, 5(1-2), 43-47.

[40] Roberts, T. L. (2014). Cadmium and phosphorusfertilizers: The issues and the science. Procedia Engineering, 83, 52-59.

[41] Samba, A. M. A. (2010). A need for an improvement in urban food security. Peace and Conflict Monitor. http://www.monitor.upeace.org/innerpg.cfm?id_article=758

[42] Santhosham, M., Chandran, A. \& Fitzwater, S. et al. (2010). Progress and barriers for the control of diarrhoeal disease. The Lancet, 376, 63-67.

[43] Shaw, R. (2010). The use of human urine as crop fertilizer in Mali, West Africa. M. Sci. thesis, Michigan Technological University. 68 pp.

[44] https://www.mtn.edu/peacecorpsprograms/civil/pdgs/ryan-shaw.thesis-final.pdf. 
[45] Sidibé, H. (2000) Agriculture urbaine et periurbaine, securité alimentaire et nutrition dans les ménages. SNV-Mali, Bamako. www.ruaf.org. 4 pp.

[46] Sims, J. T. \& Johnson, G. V. (1991).Micronutrient soil tests. In Micronutrients in Agriculture. Soil Sci. Soc. Amer., Madison, Wisconsin. Pp 427-476.

[47] Soumaré, M., Tack, F. M. G. \& Verloo, M. G. (2003).Effects of municipal solid waste compost and mineral fertilization in plant growth in two tropical agricultural soils of Mali. Bioresource Technology, 86, $15-20$.

[48] Wessels, K. R., Oédraogo, Z. P., Rouamba, N. et al. (2012). Short term zinc supplementation with dispersible tablets of zinc sulphate solution yields similar positive effects on plasma zinc concentration of young children in Burkina Faso. Journal of Pediatrics 160(1), 129-135.

[49] Wessels, K.R.\& Brown, K. H. (2012). Estimating the global prevalence of zinc deficiency: Results based on zinc availability in National Food Supplies and the Prevalence of Stunting. Plos One, 7(11),https://doi.org/10.1371/journal.pone.0050568.

[50] World Factbook (2010) https://www.cia.gov.

[51] Zemberyová, M., Barteková, J. \& Hagarová, I. (2006).The utilization of modified BCR three-step sequential extraction procedure for the fractionation of $\mathrm{Cd}, \mathrm{Cr}, \mathrm{Cu}, \mathrm{Ni}, \mathrm{Pb}$ and $\mathrm{Zn}$ in soil reference materials of different origins. Talanta, 70(5), 973-978.

[52] Zhang, L., Zeng, L, Gui, G., Duan, Y., Hu, Z. (2015).Zinc supplementation for infants and children with HIV infection. Chapter 10, pages 151-165 in Health of HIV Infected People. Academic Press.

Citation: Sanata Traoré, et.al., (2020). "Zinc in Urban/Peri-Urban Agriculture in Bamako, Mali: Effects of Closing the Nutrient Loop". International Journal of Medicinal Plants and Natural Products (IJMPNP), 6(2), pp.23-30. http://dx.doi.org/ 10.20431 /2454-7999.0602004

Copyright: (C) 2020 Authors. This is an open-access article distributed under the terms of the Creative Commons Attribution License, which permits unrestricted use, distribution, and reproduction in any medium, provided the original author and source are credited. 